\title{
O mestre revelado:
}

\section{O que aprendi com José Carlos Rodrigues}

\section{The master in close-up:}

\section{What I have learned from José Carlos Rodrigues}

\section{Marcio Goldman}

Doutor em Antropologia Social pelo Museu Nacional (UFRJ) e professor titular da mesma instituição. Bolsista de Produtividade Científica do CNPq e Bolsista Cientista do Nosso do Estado da FAPERJ. UFRJ, Programa de Pós-Graduação em Antropologia Social, Rio de Janeiro (RJ), Brasil.

O que dizer de alguém que se conhece há quase meio século, que foi o primeiro professor da disciplina que passei a vida praticando, depois meu colega e amigo de décadas? O risco, como sempre - e nele já acabo de cair - é falar mais de si mesmo do que da pessoa que aqui se homenageia. Portanto, é com desculpas e um pouco de vergonha que me limitarei a evocar memórias muito antigas, mas que, é claro, continuam muito atuais.

De fato, José Carlos Souza Rodrigues foi meu professor de Antropologia I no curso de Ciências Sociais da Universidade Federal Fluminense. Em 1976! Lembro com nitidez como esperávamos os dias de aula e ficávamos desapontados quando, por um motivo ou outro, ela não acontecia. Também lembro que, no final do semestre letivo, a turma praticamente inteira havia decidido que a antropologia seria nosso destino no campo das ciências sociais. É verdade que isso não aconteceu e que só dois ou três de nós (éramos 60 !) permaneceram fiéis a essa decisão. Provavelmente porque nenhum outro professor foi capaz de manter o encanto que José Carlos provocava em nós. 
Eu tive a certeza de que viria a ser antropólogo ao assistir a suas aulas. Em especial aquelas em que José Carlos nos expôs a teoria da proibição do incesto, de Lévi-Strauss, explicando-nos cuidadosamente por que essa proibição seria universal e por que ela fundaria a sociedade humana. Tema, convenhamos, bem estranho para um garoto de 19 anos. Mais estranho ainda, contudo, é o fato de que achei que tudo aquilo era absolutamente óbvio e que, de algum modo, eu já sabia o que ele nos estava ensinado.

Mais tarde, e por muito tempo, sempre pensei nessa experiência - que se repetiu apenas com mais uns três ou quatro autores e uns dois professores - como algo meio platônico, remetendo mais para uma espécie de revelação do que para uma pura aprendizagem. Nunca deixei de ficar intrigado com as razões para esse tipo de identificação porque é evidente que eu não sabia o que estava sendo ensinado. Minha única hipótese é que essas razões têm a ver com o modo singular pelo qual alguns autores e professores provocam emoções muito profundas por meio de caminhos aparentemente muito frios e racionais. Estilo, de que poucos são capazes, que articula argumentos racionais com sensações não exprimidas, o que acaba provocando justamente essa impressão de que já se sabia o que se está, na verdade, aprendendo. Revelação sim, mas talvez no sentido fotográfico do termo.

Para mim, esse estilo serviu como um modelo, e, durante meus primeiros anos como professor de antropologia, meus cursos emulavam o que eu havia acompanhado com José Carlos. O ponto, creio, é como ultrapassar o clichê mais usual que repete que, em antropologia, se trata, basicamente, de estranhar, desnaturalizar, desreificar... O que não é falso, mas que, se não for acompanhado de outras forças, se torna muito rapidamente outro clichê que não leva a lugar nenhum a não ser a se considerar mais esperto que os demais.

Suponho que o que deve acompanhar esses movimentos de desconstrução é o uso da contraintuição como uma força constante e ininterrupta, de modo a fazer que a relatividade das coisas não sirva para tranquilizar, mas para inquietar e para pôr o pensamento em movimento - como Roland Barthes (um dos autores do nosso curso, aliás) observou há muito tempo. De tal modo que, toda vez que achávamos que o esforço intelectual e existencial ao qual José Carlos nos obrigava estava concluído, vinha mais uma volta no parafuso, até nos darmos conta que esse trabalho não tem fim e que um professor não ensina apenas conteúdos específicos, mas um modo específico de aprender qualquer conteúdo, um modo de aprender a aprender, como ensinou Gregory Bateson. 
Em suma, trata-se, como escreveu Pierre Clastres, de enfrentar essa recusa ocidental em se aliar com "linguagens estranhas" da "loucura" e da "selvageria", recusa que trai nossa incapacidade de reconhecer e aceitar o outro como tal, e a violência "grosseira ou sutil" dela derivada. Não me parece casual, portanto, que José Carlos tenha se dedicado principalmente ao estudo dessas linguagens igualmente estranhas dos tabus corporais e da própria morte.

Eu deveria ter começado minha graduação em 1975, mas algumas circunstâncias fizeram com que isso só acontecesse em 1976. Sempre fui grato por essa sorte que me fez ter aprendido antropologia com José Carlos. E sempre admirei o destino das centenas de estudantes que também tiveram essa sorte ao longo desse longo tempo em que José Carlos vem ensinando tanta gente.

Marcio Goldman

ORCID: $h$ ttp://orcid.org/0000-0001-6594-1520

UFRJ, Programa de Pós-Graduação em Antropologia Social, Rio de Janeiro (RJ), Brasil.

Doutor em Antropologia Social / UFRJ

E-mail: marcio.goldman@gmail.com

Recebido em: 23 de agosto de 2021.

Aprovado em: 8 de setembro de 2021.

Este artigo é publicado em acesso aberto (Open Access) sob a licença Creative Commons Attribution Non-Commercial (CC-BY-NC 4.0), que permite que outros remixem, adaptem e criem a partir do seu trabalho para fins não comerciais, e embora os novos trabalhos tenham de lhe atribuir o devido crédito e não possam ser usados para fins comerciais, os usuários não têm de licenciar esses trabalhos derivados sob os mesmos termos. 